\title{
Comparative Study of Price Variations of Basic Civil Engineering Construction Materials
}

\author{
Oginni, Felix A. ${ }^{1}$, Ogunbiyi, Moses A. ${ }^{1} \&$ Balogun, Sodiq O. ${ }^{1}$ \\ ${ }^{1}$ Department of Civil Engineering, Osun State University, P.M.B. 9544, Oshogbo, Nigeria \\ Correspondence: Oginni, Felix A., Department of Civil Engineering, Osun State University, P.M.B. 9544, \\ Oshogbo, Nigeria. Tel: 234-803-722-4267. E-mail: kafnog@gmail.com/oginnifa@uniosun.edu.ng
}

Received: July 10, $2014 \quad$ Accepted: August 6, $2014 \quad$ Online Published: August 20, 2014

doi:10.5539/eer.v4n3p50 URL: http://dx.doi.org/10.5539/eer.v4n3p50

\begin{abstract}
A study of varying prices of basic civil engineering construction materials was undertaken. The basic materials considered were two varieties of cement, three types of sand, and different sizes of two types of timber. Prices of these construction materials were collected from local Contractors in Oshogbo region over a period of twenty seven months. The period considered was from January 2010 to March 2012. Variation pattern in the prices was studied on monthly basis. Results indicate that prices of all the basic construction materials follow an annual cyclic pattern. Prices of the two brands of Cement were the same except at months 12, 23 and 24. The prices are stable from April to August of each year (months 4-8, and 16-20). During these periods the price of this material increased by $13.3 \%$ from $\$ 1,500.00$ in 2010 to $\$ 1,700.00$ in 2011 . There were two rises per annum in the prices of sand. The first rise occurred in March and the second in the following November for sharp and fine sands. Timber prices are relatively stable within 5\% variability during the months of November - March and December - March respectively for hardwood and whitewood except types H4 and W1. H4 and W1 prices were the same and they followed the same trend. The trends presented by types H4 and H5, which are same size but different species, are similar, indicating that hardwood specie is not a factor in the price variation of timbers. It can generally be concluded that the prices of the basic construction materials will stabilize during the months of April to August of every year. Although construction activities are light every January, January prices keep increasing from year to year.
\end{abstract}

Keywords: prices, variation, construction, materials, management, period, cement, sand, timber

\section{Introduction}

In almost all construction projects, changes or variations are common occurrences during the design and construction phases, (Entrusty Group, 2008). The prices of construction materials fluctuate mainly due to supply, supply environment and the demand for the material for other uses. The prices of sawn wood and other forest products fluctuate mainly due to supply and demand.

The major construction materials in the field of civil engineering include the following:

Cement, Sand (sharp sand, fine/plastic sand), Granite, Hardcore, Reinforcement Bars, Timbers, Structural steel frames.

Construction is a complex process that exhibits a high degree of uncertainty. The following are factors affecting prices of construction materials:

Size of project; Location of the project; Environment of the project; Political climate; Award season; War situation; Economic climate; Exposure of the Contractor; Regional variation; Disparity in pricing importation.

Ssegawa et al., 2002 indicated that it is hardly possible to complete a project without changes to the plans or the construction process. This makes variation to become so prevalent in construction works. Revay, 2002 stated that this may lead to changes to scope, time, cost and/or quality on most, if not all, construction projects. Various studies have identified variation orders among the causes of project cost and time overruns, which Sterman, 1992 considered as endemic problems in international construction. Tyagi and Kushwaha, 2012 proposed the revision of the price variation clause first in using the price indices to be followed by the use of the revised PVC for updating the rates. Makwana and Pitroda, 2013 used frequency analysis in studying region wise price variation 
of construction raw materials. Other workers in this field include Oladapo, 2007; Entrusty Group, 2008; Evija Greǵe - Staltmane, 2009; Kalu et. al., 2009; Arowosoge et. al, 2011 and Long, 2013.

Generally, it has been estimated that building materials and components constitute between 50 to 60 percent of the total cost of construction. Okupe, 2000, observed that the cost could be about 75 percent in Nigeria. He outlined factors contributing to this to include inadequate infrastructural facilities like bad roads, which may increase the cost of delivery of materials and tariffs charged on the materials that also shoot up the price.

Duration of major Civil Engineering projects on the average is about three years. Within the period of project execution and delivery, major construction materials exhibit price variations. These variations may have a direct impact on the lifespan of the project.

Factors affecting the prices of construction materials vary with the type of construction material under consideration. The materials can be categorized according to the level of local contents and inputs in their production. Cost of production of cement, iron rods and steel frames have low local contents/inputs. Factors contributing to the variation in pricing of these materials in Nigeria include the following:

Cost of production Impact of production scale Transportation infrastructure

Regional variation in demand and supply Disparity in pricing-importation.

Cost of production of sand, granite and timber have high local contents/inputs. Variation in prices of these materials depends on vegetation and climatic factors within the region of the country. They may also be affected by seasonal factors. Aje, 1995 revealed that finishes and substructure are the building elements that attract the highest percentage of variation on building projects. Izekor and Izekor, 2011 revealed that factors that account for variations in the prices of sawn timber in Benin Metropolis, in Nigeria include transportation cost representing $40 \%$, seasonality (42\%) and power supply (18\%). Variations within an area depends on constraints to delivery within the area, general constraints to delivery within the production center/sector seasons - festival, weather related constraints. The scope of this study is limited to a South Western Nigeria vegetation zone.

\section{Materials and Methods}

The construction materials considered in this study are as follows:

2 brands of Cement, Elephant cement and Dangote cement

3 types of sand, laterite, fine sand and sharp sand

2 types of timber, hardwood and whitewood

The 2 types of timber are further considered on the basis of the following sizes:

$25 \mathrm{~mm} \times 300 \mathrm{~mm} \times 3600 \mathrm{~mm}$

$50 \mathrm{~mm} \times 75 \mathrm{~mm} \times 3600 \mathrm{~mm}$

$50 \mathrm{~mm} \times 100 \mathrm{~mm} \times 3600 \mathrm{~mm}$

$75 \mathrm{~mm} \times 100 \mathrm{~mm} \times 3600 \mathrm{~mm}(50 \mathrm{~mm} \times 150 \mathrm{~mm} \times 3600 \mathrm{~mm})$

The various types of hardwood are denoted as H1, H2, H3, H4, and H5and are described respectively as indicated below:

Type H1 - Harwood (Ayunre, ire, ila, ayo ire) $25 \mathrm{~mm} * 300 \mathrm{~mm} * 3600 \mathrm{~mm}$

Type H2 - Hardwood (Mahogany, Idigbo, Osun) 50mm*75mm*3600mm

Type H3 - Harwood (Ayunre, ire, ila, ayo ire, e.t.c) $50 \mathrm{~mm} * 100 \mathrm{~mm} * 3600 \mathrm{~mm}$

Type H4 - Harwood (Ayunre, ire) $75 \mathrm{~mm} * 100 \mathrm{~mm} * 3600 \mathrm{~mm}(50 \mathrm{~mm} * 150 \mathrm{~mm} * 3600 \mathrm{~mm}$ )

Type H5 - Harwood (Mahogany, etc) $75 \mathrm{~mm} * 100 \mathrm{~mm} * 3600 \mathrm{~mm}(50 \mathrm{~mm} * 150 \mathrm{~mm} * 3600 \mathrm{~mm}$ )

Types $\mathrm{H} 4$ and $\mathrm{H} 5$ are of the same size but of different species.

The various types of whitewood are denoted as W1, W2, and W5and described as indicated below.

Type W1 - Whitewood (Oro, Opon, Eapu, Ofee) 25mm*300mm*3658mm type prices

Type W2 - Whitewood (Oro, Opon, Eapu) 50mm*75mm*3658mm type prices

Type W3 - Whitewood (Oro, Opon, Eapu, Ofee,) 50mm*100mm*3658mm type price

\subsection{Data Collection}

Monthly prices of the construction materials were collected for the 2 brands of cement, 3 types of sand, and 2 
types timbers (of various sizes), from Retail Dealers around Olaiya area in Oshogbo, Osun state. The data collected was for a period of twenty seven calendar months spanning from January 2010 to March 2012.

The prices of the two brands of cement and three types of fine aggregates, sharp sand, fine sand and lateritic soil materials considered in the study are presented in Table 1.

Table 1. Monthly prices of 2 brands of cement (Dangote and Elephant) and 3 types of sand

\begin{tabular}{|c|c|c|c|c|c|c|c|}
\hline \multirow[b]{2}{*}{ Year } & \multirow[b]{2}{*}{ Month } & \multirow[b]{2}{*}{$\mathrm{N}^{\text {th }}$ month } & \multicolumn{2}{|c|}{ Cement Price/Type ( $/$ /bag) } & \multicolumn{3}{|c|}{ Sand Price / Type $\left(\$ / 5 \mathrm{~m}^{3}\right.$ Tipper load $)$} \\
\hline & & & Dangote & Elephant & Sharp Sand & Fine Sand & Laterite \\
\hline 2010 & January & 1 & 1625 & 1625 & 3000 & 3000 & 4500 \\
\hline 2010 & February & 2 & 1625 & 1625 & 3000 & 3000 & 4500 \\
\hline 2010 & March & 3 & 1575 & 1575 & 3500 & 3500 & 5000 \\
\hline 2010 & April & 4 & 1500 & 1500 & 3500 & 3500 & 5000 \\
\hline 2010 & May & 5 & 1500 & 1500 & 3500 & 3500 & 5000 \\
\hline 2010 & June & 6 & 1500 & 1500 & 3500 & 3500 & 5000 \\
\hline 2010 & July & 7 & 1500 & 1500 & 3500 & 3500 & 5000 \\
\hline 2010 & August & 8 & 1500 & 1500 & 3500 & 3500 & 5000 \\
\hline 2010 & September & 9 & 1625 & 1650 & 3500 & 3500 & 5500 \\
\hline 2010 & October & 10 & 1625 & 1650 & 3500 & 3500 & 5500 \\
\hline 2010 & November & 11 & 1700 & 1700 & 4000 & 4000 & 5500 \\
\hline 2010 & December & 12 & 1750 & 1900 & 4000 & 4000 & 5500 \\
\hline 2011 & January & 13 & 1900 & 1875 & 4000 & 3500 & 4000 \\
\hline 2011 & February & 14 & 1900 & 1875 & 4000 & 3500 & 4000 \\
\hline 2011 & March & 15 & 1800 & 1800 & 4500 & 4000 & 4500 \\
\hline 2011 & April & 16 & 1700 & 1700 & 3500 & 4000 & 4500 \\
\hline 2011 & May & 17 & 1700 & 1700 & 3500 & 4000 & 4500 \\
\hline 2011 & June & 18 & 1700 & 1700 & 3500 & 4000 & 4500 \\
\hline 2011 & July & 19 & 1700 & 1700 & 3500 & 4000 & 4500 \\
\hline 2011 & August & 20 & 1700 & 1700 & 3500 & 4000 & 4500 \\
\hline 2011 & September & 21 & 1900 & 1875 & 5000 & 4000 & 5000 \\
\hline 2011 & October & 22 & 1950 & 1950 & 5000 & 4000 & 5000 \\
\hline 2011 & November & 23 & 1950 & 2000 & 5000 & 4500 & 5000 \\
\hline 2011 & December & 24 & 2300 & 2300 & 5000 & 4500 & 5000 \\
\hline 2012 & January & 25 & 2250 & 2150 & 6000 & 3000 & 6000 \\
\hline 2012 & February & 26 & 2150 & 2150 & 6000 & 3000 & 6000 \\
\hline 2012 & March & 27 & 1725 & 1750 & 6000 & 3500 & 6000 \\
\hline
\end{tabular}

Prices of the two types of timber, (hardwood and whitewood) for basic sizes which are used in construction works, denoted as H1, H2, H3, H4, H5, W1, W2, and W3 are shown in Table 2.

Table 2. Monthly prices of wood types

\begin{tabular}{lllllllllll}
\hline & & & \multicolumn{1}{c}{ Price/ Wood Type } & $(\mathbf{N})$ \\
Year & Month & $\mathbf{N}^{\text {th }}$ month & H1 & H2 & H3 & H4 & H5 & W1 & W2 & W3 \\
\hline 2010 & January & 1 & 1300 & 330 & 430 & 660 & 600 & 660 & 200 & 320 \\
2010 & February & 2 & 1300 & 330 & 430 & 660 & 600 & 660 & 200 & 320 \\
2010 & March & 3 & 1300 & 330 & 430 & 660 & 600 & 660 & 200 & 320 \\
2010 & April & 4 & 1350 & 345 & 435 & 690 & 650 & 690 & 230 & 340 \\
2010 & May & 5 & 1350 & 345 & 435 & 690 & 650 & 690 & 230 & 340 \\
2010 & June & 6 & 1350 & 345 & 435 & 690 & 650 & 690 & 230 & 340 \\
2010 & July & 7 & 1350 & 345 & 435 & 690 & 650 & 690 & 230 & 340 \\
2010 & August & 8 & 1350 & 345 & 435 & 690 & 650 & 690 & 230 & 340 \\
2010 & September & 9 & 1300 & 335 & 430 & 670 & 650 & 670 & 230 & 340 \\
2010 & October & 10 & 1300 & 335 & 430 & 670 & 630 & 670 & 200 & 330 \\
2010 & November & 11 & 1350 & 345 & 430 & 670 & 630 & 670 & 200 & 330 \\
2010 & December & 12 & 1350 & 345 & 430 & 670 & 650 & 670 & 230 & 340 \\
2011 & January & 13 & 1350 & 350 & 440 & 700 & 650 & 700 & 230 & 340 \\
\hline
\end{tabular}




\begin{tabular}{lllllllllll}
\hline 2011 & February & 14 & 1350 & 350 & 440 & 700 & 650 & 700 & 230 & 340 \\
2011 & March & 15 & 1350 & 350 & 440 & 700 & 650 & 700 & 230 & 340 \\
2011 & April & 16 & 1450 & 380 & 445 & 760 & 700 & 760 & 250 & 350 \\
2011 & May & 17 & 1450 & 380 & 445 & 760 & 700 & 760 & 250 & 350 \\
2011 & June & 18 & 1450 & 380 & 445 & 760 & 700 & 760 & 250 & 350 \\
2011 & July & 19 & 1450 & 380 & 445 & 760 & 700 & 760 & 250 & 350 \\
2011 & August & 20 & 1450 & 380 & 445 & 760 & 700 & 760 & 250 & 350 \\
2011 & September & 21 & 1350 & 360 & 440 & 720 & 700 & 720 & 250 & 350 \\
2011 & October & 22 & 1350 & 360 & 440 & 720 & 680 & 720 & 230 & 350 \\
2011 & November & 23 & 1450 & 380 & 440 & 720 & 680 & 720 & 230 & 350 \\
2011 & December & 24 & 1450 & 380 & 440 & 720 & 700 & 720 & 250 & 350 \\
2012 & January & 25 & 1450 & 400 & 450 & 800 & 700 & 800 & 250 & 350 \\
2012 & February & 26 & 1450 & 400 & 450 & 800 & 700 & 800 & 250 & 350 \\
2012 & March & 27 & 1450 & 400 & 460 & 800 & 700 & 800 & 250 & 350 \\
\hline
\end{tabular}

\section{Results and Analysis}

\subsection{Cement Price Variation}

The variation in price of Cement not minding the brand can be seen to follow an annual pattern. The price presents an annual variation. These are shown in Fig. 1.

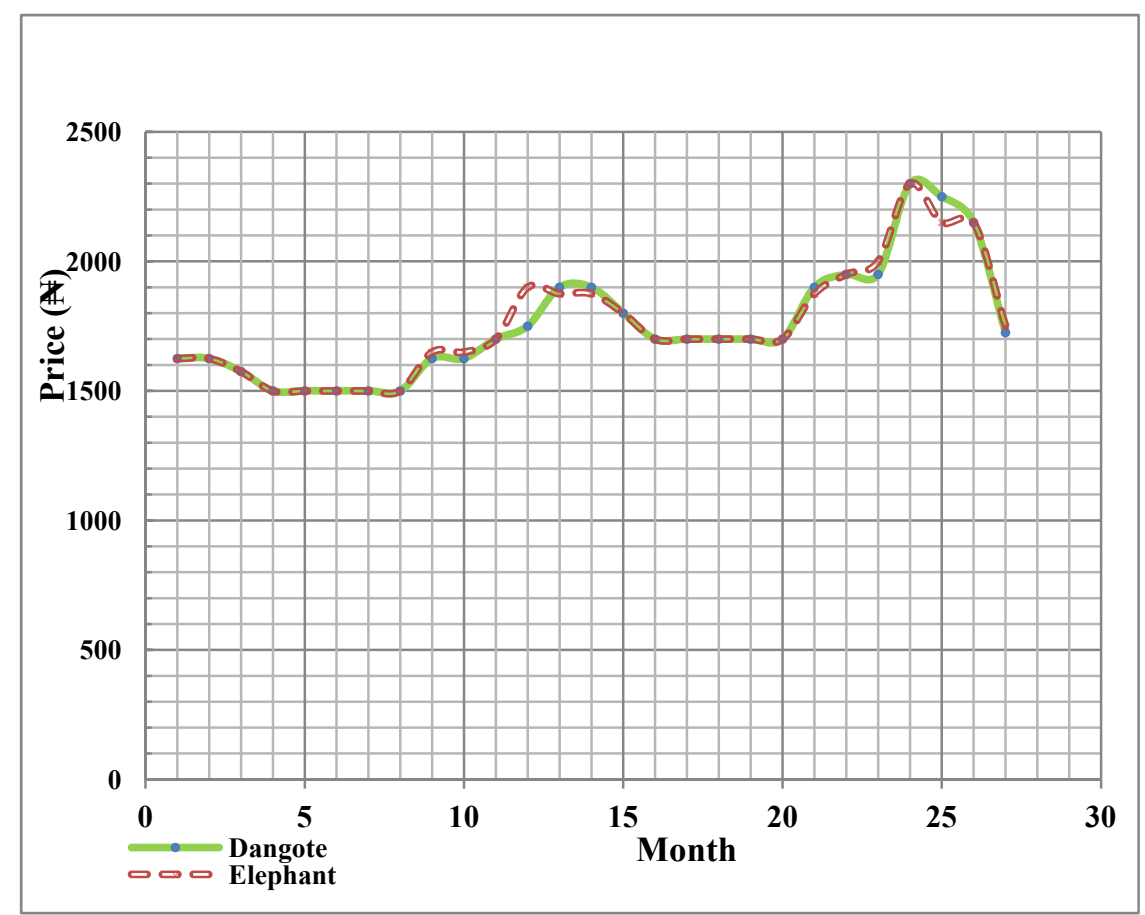

Fig. 1. Variation of Dangote and Elephant cement prices from Jan 2010 - March 2012

Price of Elephant cement has two peaks during the period of study. The first peak was at month 12 while the second was 12 months later at month 24. Price of Dangote cement also has two peaks during the period of study, though it reached its first peak, a month after that of Elephant Cement at month 13 through month 14. This implies that Dangote cement prices had to wait a month after Elephant cement prices. Generally the prices of the two brands of Cement were the same except at months 12, 23 and 24 as shown in Fig. 1. It can also be observed that there is price stability from April to August of each year (months 4-8, and 16-20). During these periods the price of this material increased by $13.3 \%$ from $\$ 1,500.00$ in 2010 to $\$ 1,700.00$ in 2011. 


\subsection{Analysis of Price Variation of Sand}

The first eight months of year 2010, showed that from January, the prices of fine sand, sharp sand and laterite rose from $\$ 3,000, \$ 3,000$ and $\$ 4,500$ respectively in February by $\$ 500$. This implies a $16.67 \%$ increase for the fine and sharp types of sand, and just $11.11 \%$ for laterite. These prices remained stable for eight months after which it experienced another rise of $\$ 500$, except that of laterite that was stable for 6 months before the rise of another $\$ 500$ in the following month 9. These are shown in Fig. 2.

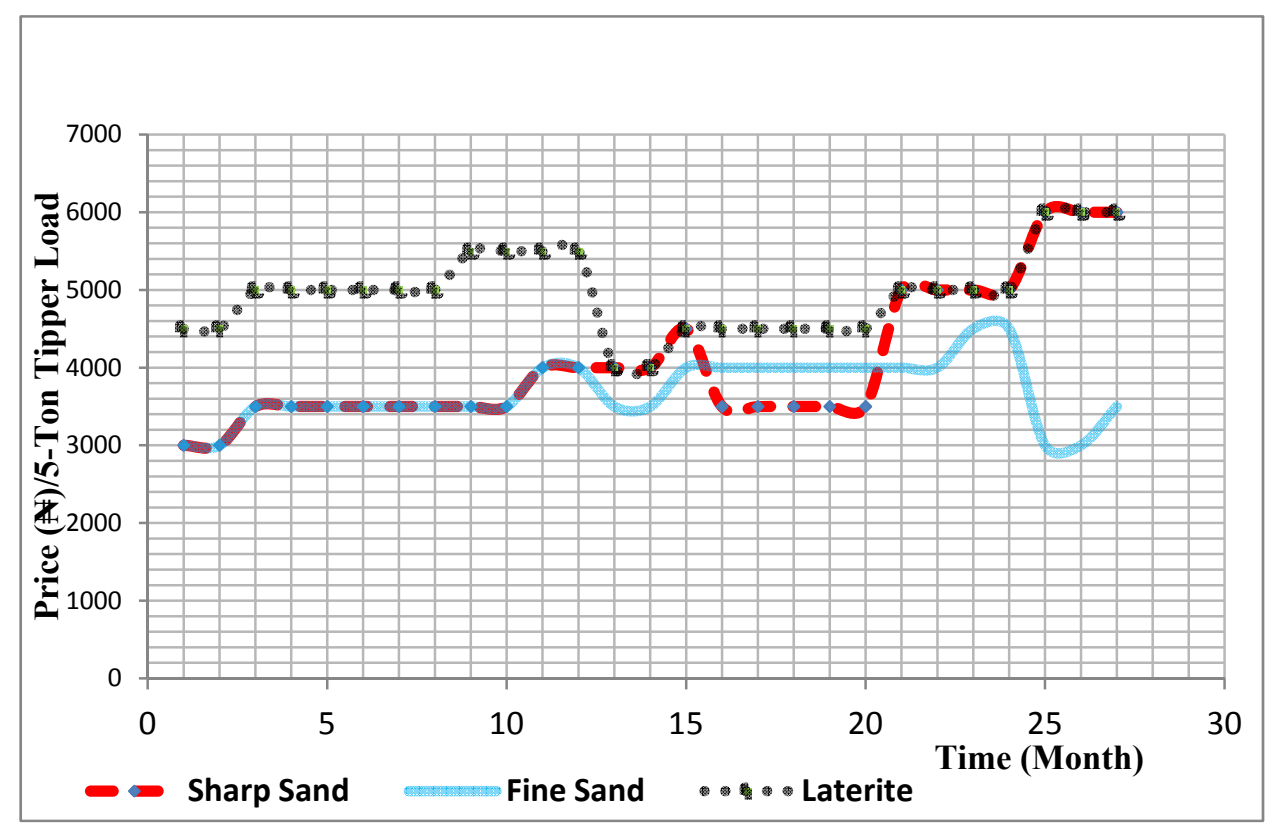

Fig. 2. Price Variation of fine sand, sharp sand and laterite from Jan. 2010 - Mar. 2012

Prices of fine sand and laterite stabilized for 2 and 4 months respectively from November and September to December of year 2010. Price of sharp sand stabilized for 4 months at $\$ 4,000$ from month 11 to month 14 (February 2011) before another $\$ 500$ increase in a unit of 5-ton tipper load. This is followed by a fall of 1,000 in month 16 which then stabilized for 5 months from month 16 to 20 . This price rose by 1,500 in month 21 and stabilized for the next 4 months, another end of year (month 24). It then rose by $\$ 1,200$ stabilizing there till month 27. The price of laterite followed similar pattern to that of fine sand, except in month 24 when price of laterite fell sharply by $\$ 1,500$ from $\$ 4,500$ to $\$ 3,000$.

Generally all the sharp and fine sands and the laterite experienced 5 rises or 4 rises in 2 years at the rate of twice / year. The first rise was observed in March while the second was observed in November for sharp and fine sands. Laterite and sharp sand experienced only one fall in price, while fine sand had two falls during the study period. Prices of these materials can be said to follow an annual pattern of rise and fall dictated by end of year festivity periods, and the level of economic activities within the year using cement price pattern as an indicator of the level of economic activity. Increases are mostly \$500/5-Ton tipper load considered except after the second year. It is also observed that when the price of cement begins to fall, that of sands begins to rise.

\subsection{Analysis of Price Variation of Timber Types, Species and Sizes}

The general trend in price variation of hardwood types and sizes except type $\mathrm{H} 3$ are noticed during the months of March and April, as indicated in months 3 and 4 and months 15 and 16 respectively. These trends are shown in Fig. 3. April to August experienced stable timber prices. Lower prices are experienced in the months of September and November. Price of timber Type H3 increases steadily at the rate of $0.26 \%$ from January 2010 to 7\% in March 2012.

Timber prices are relatively stable within 5\% variability during the months of November to the following March, as indicated in months 11-15 and 23-27 in Fig. 3, with the exception of type H4. The trends presented by types $\mathrm{H} 4$ and H5, which are same size but different species, are similar. This indicates that specie is not a factor in the price variation of timbers. 


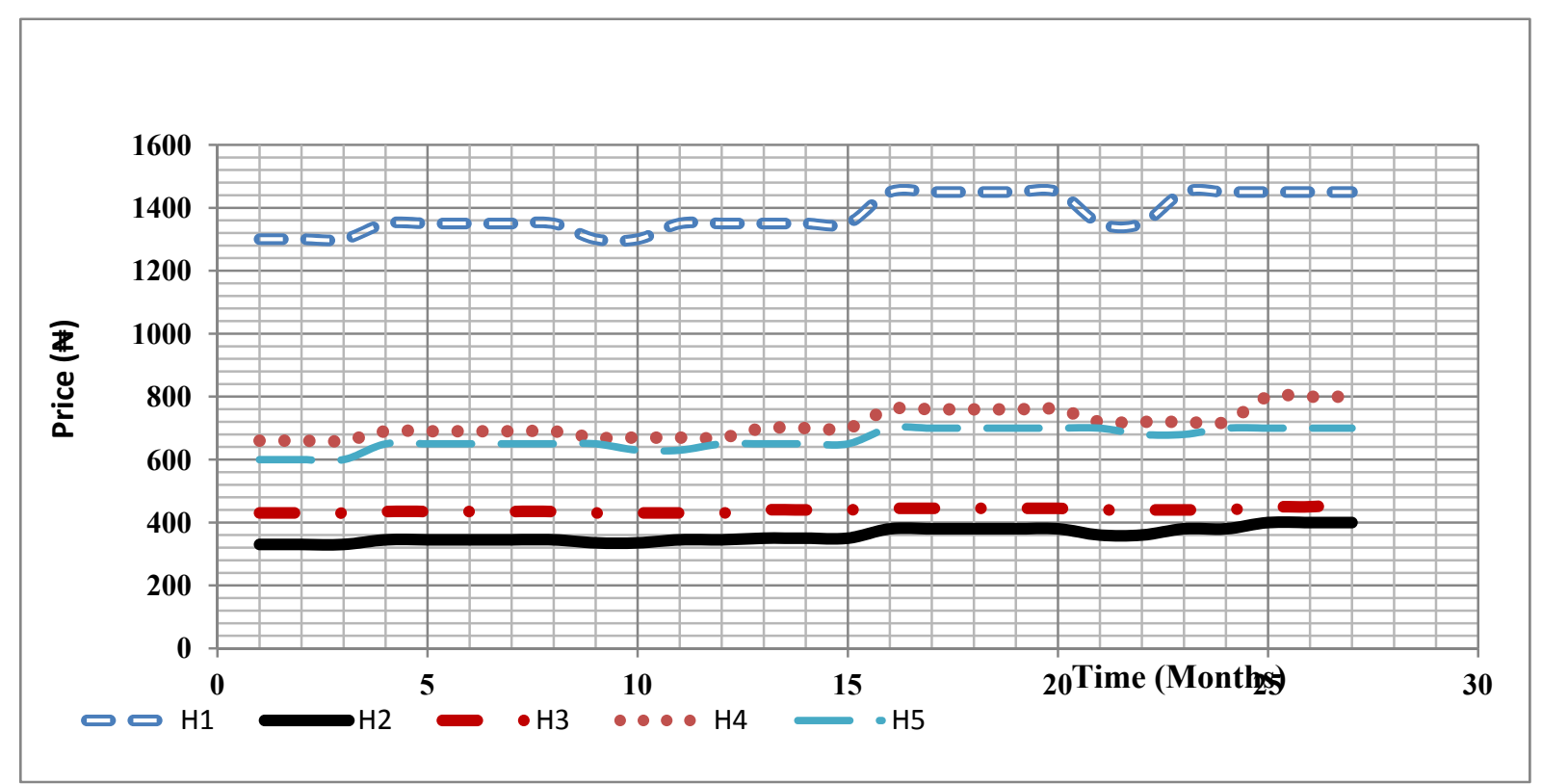

Fig. 3. Variation in prices of hardwood of different species and sizes from Jan. 2010 - Mar. 2012

A general trend of price increase for whitewood types and sizes is noticed between the months of March and April, as indicated in Fig. 4 for months 3 and 4 and months 15 and 16 respectively. The price stabilized for at least five months for type W1 and six months for Types W2 and W3. This implies that the months of April to August experience stable timber prices. Generally, relatively lower prices are experienced in the months of October and November.

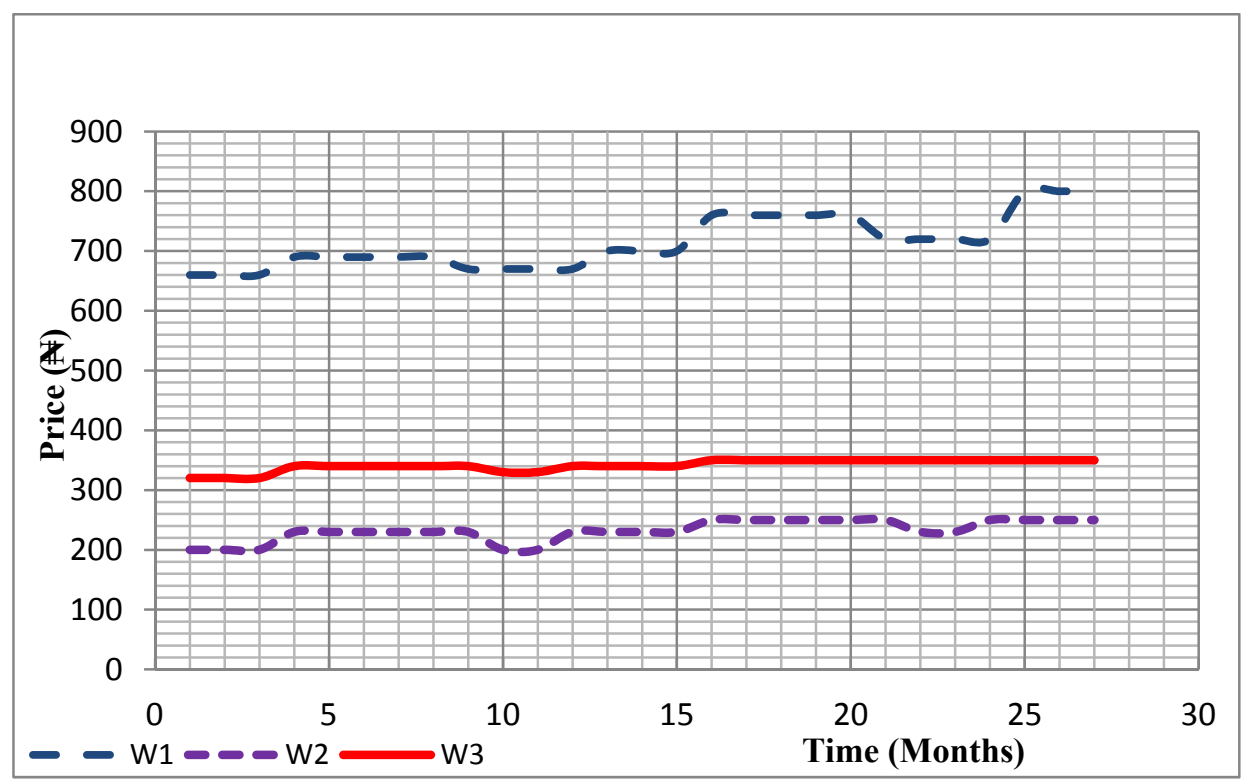

Fig. 4. Variation in prices of whitewood of different sizes from Jan. 2010 - Mar. 2012

Whitewood prices are relatively stable within 5\% variability during the months of December to the following March, as indicated in months 12-15 and 24-27, with the exception of type W1.

$\mathrm{H} 4$ and $\mathrm{W} 1$ prices are the same and they follow the same trend.

Probable reasons for the cyclic trend in the variation of the prices of the basic construction materials are that 
more construction works take place during the annual dry season. Most people want to complete especially their building construction works so as to have something to show for the year before it runs out. This makes December the peak of civil engineering construction activities, with associated temporal peak demand for construction materials.

\section{Conclusion and Recommendation}

Analysis of the price variations for the basic construction materials investigated revealed as follows:

Prices of all the basic construction materials follow an annual cyclic pattern.

By February of each year, the price of cement begins to fall while that of sand begins to rise with the exception of fine sand which had a delay of rising by a month in the third year of study.

Prices of the two brands of Cement were the same except at months 12, 23 and 24 and there is price stability from April to August of each year (months 4-8, and 16-20). During these periods the price of this material increased by $13.3 \%$ from $\$ 1,500.00$ in 2010 to $\$ 1,700.00$ in 2011 .

Increases in price of sand are mostly $\$ 500 / 5$-Ton Tipper load except in the beginning of 2012. It can be concluded that there are there are 2 rises per annum in the prices of sand. The first rise occurred in March and the second in the following November for sharp and fine sands.

Prices of all types of timber except H3, increases by April and stabilizes through August. Lower prices are experienced in the months of September and November for types H1, H2, H4, H5, and W1; and October and November for types W2 and W3. Price of timber Type H3 increases steadily at the rate of $0.26 \%$ from January 2010 to $7 \%$ in March 2012.

The trends presented by types $\mathrm{H} 4$ and H5, which are same size but different species, are similar, indicating that hardwood specie is not a factor in the price variation of timbers.

Timber prices are relatively stable within 5\% variability during the months of November - March and December - March respectively for hardwood and whitewood except types H4 and W1. H4 and W1 prices are the same and they follow the same trend.

It can generally be concluded that the prices of the basic construction materials stabilize during the months of April to August of every year. Although construction activities are light every January, January prices keep increasing from year to year.

Considering that price variation of construction materials can be a function of local contents factors, political, festival and weather related factors, it is recommended that more work can be extended to determine the levels at which each factor can affect price variation.

\section{References}

Aje Olanivi Isaac. (2000). The effect of Variation on Construction Cost and Contract Period of Building Projects. An M. Tech. (Quantity Surveying) Thesis in The Department of Quantity Surveying, Federal University of Technology, Akure. August, 2000.

Arowosoge, O. G. E., Ogunsanwo, O. Y., \& Labode, P. (2011). Spatial And Temporal Price Variations of Sawn Wood Utilized For Furniture Making In Selected Cities in Nigeria. Journal of Agriculture and Social Research (JASR), 11(1), 2011.

Entrusty, G. (2008). What Constitute Variations And How To Evaluate Them? Your Contractual Questions Answered. Master Builders MBAM Journal $4^{\text {th }}$ Quarter 2008 HT Ong at 22-1\& 2 Jalan 2/109E, Desa Business Park, Taman Desa, 58100 Kuala Lumpur, Malaysia.

Evija, G. S. (2009). Standing timber prices and factors which affect them. Forest Faculty, Woodworking department Latvia University of Agriculture Dobeles street 41, Jelgava, LV 3001, 2009.

Izekor, D. N., \& Izekor, O. B. (2011). Analysis Of Sawn Timber Enterprise In Benin Metropolis, Edo State, Nigeria. Nigerian Journal of Agriculture, Food and Environment, NJAFE, 7(2), 19-23.

Kalu, C., Atagana, S., \& Ani, P. I. (2009). Marketing of Round Logs in Benin City, Edo State, Nigeria. Journal of Applied Sciences Research, 5(7), 785-789. INSInet Publication.

Long, R. J. (2013). Construction Claims for Variation in Quantity. Long International Inc. 2013. Retrieved from www.long-intl.com

Makwana, A. H., \& Jayeshkumar P. (2013). A Study on Region wise Price Variation of Construction Raw Materials using Frequency Analysis through SPSS Software. International Journal of Engineering Trends 
and Technology (IJETT), 4(7).

Okupe, L. (2000). The Role of Private Sector in Nigeria. A seminar paper on Effective Approach to Housing. The Yaba Journal of Environmental Research. School of Environmental Studies Yaba College of Technology.

Oladapo, A. A. (2007). A quantitative assessment of the cost and time impact of variation orders on construction projects. Journal of Engineering, Design and Technology, 5(1), 35-48. Emerald Group Publishing Limited. http://dx.doi.org/10.1108/17260530710746597

Revay, S. O. (2002). Coping with extras, The Revay Report, Vol. 21.

Ssegawa, J. K., Mfolwe, K. M., Makuke, B., \& Kutua, B. (2002). Construction variations: A scourge or a necessity. Proceedings of the 1st CIB-W107 International Conference on Creating a Sustainable Construction Industry in Developing Countries, Cape Town, South Africa.

Sterman, J. D (1992). Systems Dynamic Modelling for Project Management, Sloan School of Management, MIT Cambridge.

Vishvas, K. T., \& Kushwaha, R. C. (2012). Development of methodology for revision of Price Variation Clauses for Track Fittings. A project undertaken as a part of the Senior Professional Course (P. Way) Course no 12207 from 18-06-2012 to 13-07-2012 for Indian Railways Institute of Civil Engineering, Pune, July-2012.

\section{Copyrights}

Copyright for this article is retained by the author(s), with first publication rights granted to the journal.

This is an open-access article distributed under the terms and conditions of the Creative Commons Attribution license (http://creativecommons.org/licenses/by/3.0/). 